\title{
Gambaran Tingkat Pengetahuan Petugas Tentang Sistem Informasi Manajemen Puskesmas di Puskesmas Ciwaru Kabupaten Kuningan
}

\section{Description of Officer's Level of Knowledge About Puskesmas Manajement Information System at Ciwaru Puskesmas, Kuningan Regency}

\author{
Sinta Wati ${ }^{1}$, Imas Masturoh ${ }^{2}$ \\ ${ }^{1,2}$ Politeknik Kesehatan KemenkesTasikmalaya \\ 1,2 Jl Cilolohan No 35 Kota Tasikmalaya Kode pos: 46115 \\ *e-mail korespodensi: $\underline{\text { sintawati911@gmail.com }}{ }^{1}$, imas.mth@ gmail.com ${ }^{2}$
}

\begin{abstract}
Abstrak
Era Revolusi industri 4.0 memiliki arti bahwa seluruh penyampaian informasi dilakukan dengan internet sehingga dapat mempermudah penyampaian informasi. Salah satu penerapannya yaitu melalui penggunaan Sistem Informasi Manajemen Puskesmas. Berdasarkan studi pendahuluan menunjukan bahwa tingkat pengetahuan petugas tentang Sistem Informasi Manajemen Puskesmas masih ada yang kurang. hal ini menyebabkam penggunaan SIMPUS terhambat. Tujuan penelitian ini untuk mengetahui tingkat pengetahuan petugas tentang Sistem Informasi Manajemen Puskesmas di Puskesmas Ciwaru. Jenis penelitian yang digunakan yaitu penelitian kuantitatif dengan desain penelitian deskriptif. Instrumen yang digunakan yaitu lembar kuesioner, dengan cara pengumpulan data yaitu pengisian kuesioner oleh petugas puskesmas. Analisis data yaitu analisis univariat. Hasil penelitian menunjukkan bahwa tingkat pengetahuan petugas di pendaftaran dengan kategori Cukup $(61,54 \%)$ dan kategori Kurang $(7,69 \%)$. Bagian input data menunjukkan bahwa $100 \%$ kurang. Bagian pelaporan menunjukkan bahwa nilai tertinggi pada kategori Cukup $(76,92 \%)$ dan terendah pada kategori Baik $(3,85 \%)$. Simpulan dari penelitian ini yaitu tingkat pengetahuan petugas tentang SIKDA Generik terdapat pada kategori cukup dan kurang, hal ini dikarenakan sosialisasi yang diberikan belum efektif, sehingga untuk meningkatkan tingkat pengetahuan sebaiknya dilakukan sosialisasi kembali kepada petugas puskesmas.
\end{abstract}

Kata Kunci : Pengetahuan, Sistem Informasi Manajemen Puskesmas, Sistem Informasi Kesehatan Daerah (SIKDA) Generik.

\begin{abstract}
The industrial revolution of 4.0 mean that the whole presentation of information was done on the Internet and thus facilitated the transmission of information.One of application is through the use of the center management information system. Based a preliminary study indicates that the officer's knowledge level of the center management information system is categorized by qiute $90 \%$ and a less that $10 \%$ category, this leads to stunted SIMPUS use. The purpose of this study is to find out the officer's knowledge about the application of information system for cnter management in the Ciwaru Center.The type of research is quantitative research with descriptive design.The instrument used is a questionnaire, with collecting data is filling out the questionnaire by the officer.Data analysis is univariate. Research Result show that the level of knowledge of officers at registration with sufficient category $(61,54 \%)$ and less category $(7,69 \%)$.The data input shows that less category $(100 \%)$.The reporting shows that the high score in sufficient category $(76,92 \%)$ and low score in good category $(3,85)$. The conclusions of this research are the officer's knowledge of SIKDA Generic comes in sufficient and inadequate categories. This is because socialization was not effective yet, to increase the knowledge level should be carried out socialization again.
\end{abstract}

Keywords: Knowledge, Public Health Center Management Information System, Generic Regional Health Information System (SIKDA). 


\section{PENDAHULUAN}

Era Revolusi industri 4.0 memiliki arti bahwa seluruh penyampaian informasi dapat dilakukan dengan internet sehingga hal tersebut dapat mempermudah penyampaian informasi di era digitalisasi, tidak hanya itu tren komputerisasi saat ini mengalami perkembangan yang sangat pesat. Salah satu penerapannya yaitu melalui sistem pelayanan dengan memanfaatkan teknologi informasi melalui penggunaan sistem informasi berbasis elektronik. Sistem Informasi merupakan sebuah alat atau sarana yang bertujuan untuk mengolah data menjadi informasi, yang dapat dimanfaatkan oleh pengambil keputusan. Sistem informasi juga dapat diartikan sebagai sebuah media untuk membagikan dan menyebarluaskan informasi kepada pengguna informasi secara cepat dan tepat (Hakam,2016). Pengguna sistem informasi akan melakukan 3 tahap yaitu input data, kemudian data akan di proses sehingga menjadi sebuah informasi kesehatan. Sistem informasi kesehatan menurut World Health Organization (2004) adalah sebuah sistem yang mengintegrasikan pengumpulan data, pengolahan, pelaporan, dan penggunaan informasi untuk meningkatkan efektivitas dan efisiensi pelayanan kesehatan melalui manajemen yang lebih baik. Puskesmas wajib melakukan kegiatan Sistem Informasi Puskesmas yang dapat diselenggarakan secara elektronik maupun non elektronik (Dinkes Yogya, 2016).

Pengiriman informasi yang dilakukan secara online di fasilitas pelayanan kesehatan tingkat pertama (Puskesmas) dapat melalui sebuah aplikasi Sistem Informasi manajemen Puskesmas atau yang lebih dikenal dengan SIMPUS. Sistem Informasi Manajemen Puskesmas (SIMPUS) merupakan suatu tatanan yang menyediakan informasi untuk membantu proses pengambilan keputusan dalam melaksanakan manajemen Puskesmas dalam mencapai sasaran kegiatan nya. Tahapan yang dilakukan oleh pengguna sistem informasi dilakukan dengan tiga tahap yaitu input data, proses data, data yang telah diolah menjadi sebuah informasi. Pelayanan yang efektif dan efisien dalam penggunaan SIMPUS akan tercapai apabila sumber daya manusia memiliki tingkat pengetahuan yang baik.

Pengetahuan merupakan hasil tahu seseorang terhadap objek melalui indera yang dimilikinya. Pengetahuan seseorang akan berbeda, tergantung dari bagaimana penginderaannya terhadap suatu objek. Pengetahuan memiliki hubungan yang erat dengan pendidikan yang ditempuh oleh seseorang, semakin tinggi tingkat pendidikan seseorang maka akan semakin luas pengetahuannya, namun orang yang berpendidikan rendah tidak mutlak memiliki pengetahuan yang rendah.

Penelitian Wiguna (2016) tentang Tingkat Pengetahuan Petugas Rekam Medis Terhadap Pelaksanaan Sistem Informasi Di Puskesmas Payung Kecamatan Payung Kaupaten Karo Tahun 2016 menunjukan bahwa, kurang efektifnya sistem informasi puskesmas di Unit rekam medis, terdapat beberapa hal yang memicu sistem informasi puskesmas tidak akurat salah satunya kurangnya pengetahuan petugas rekam medis terhadap prosedur sistem informasi di unit rekam medis dengan presentase sebanyak 33,3\%. Hal ini dapat menimbulkan berbagai permasalahan dalam prosedur kerja, yaitu rekam medis tidak tertata dengan rapih sehingga memperlambat proses pencarian rekam medis ketika akan digunakan, petugas mengalami kesulitan dalam pencatatan laporan harian, mingguan, bulanan, tahunan, dan sistem pelaporan mengalami keterlambatan pengiriman karena sistem pelaporan yang digunakan masih manual.

Berdasarkan studi pendahuluan menunjukan bahwa aktivitas pelayanan kesehatan di UPTD Puskesmas Ciwaru dilakukan secara elektronik namun terdapat kendala pada pengaplikasian nya, hal tersebut dikarenakan kurangnya tingkat pengetahuan petugas tentang penggunaan Sistem Informasi Kesehatan Daerah (SIKDA) Generik. Hal tersebut

p-ISSN: $\quad$ e-ISSN: 2807-2596

website: ijhim.stikesmhk.ac.id/index.php/ 
didukung oleh hasil uji coba kuesioner kepada 10 petugas menunjukan bahwa tingkat pengetahuan petugas tentang Sistem Informasi Kesehatan Daerah (SIKDA) Generik dengan kategori cukup $90 \%$, dan kategori kurang $10 \%$. Tujuan penelitian ini yaitu untuk mengetahui tingkat pengetahuan petugas tentang aplikasi Sistem Informasi Manajemen Puskesmas di UPTD Puskesmas Ciwaru.

\section{METODE PENELITIAN}

Jenis penelitian yang digunakan yaitu peneltian kuantitatif dengan desain desktiptif. Subjek penelitian yang digunakan yaitu petugas puskesmas sebanyak 26 orang. Instrumen yang digunakan dalam penelitian ini yaitu lembar kuesioner. Cara pengumpulan data dalam penelitian ini yaitu petugas mengisi lembar kuesioner untuk mengukur tingkat pengetahuan petugas tentang SIKDA Generik. Tahapan pengolahan data dimulai dari Editing, Coding, dan Processing . Data dianalisis menggunakan analisis univariat untuk mendeskripsikan tingkat pengetahuan petugas tentang SIKDA Generik.

\section{HASIL}

Hasil penelitian yang dilakukan di UPTD Puskesmas Ciwaru, Kabupaten Kuningan tentang Gambaran Tingkat Pengetahuan Petugas tentang Sistem Informasi Kesehatan Daerah (SIKDA) Generik di Puskesmas Ciwaru sebagai berikut:

\section{Berdasarkan Karakteristik Responden}

Tabel 1. Tabulasi Silang Tingkat Pengetahuan Petugas Berdasarkan Usia

\begin{tabular}{ccccccccc}
\hline \multirow{2}{*}{ Usia } & \multicolumn{9}{c}{ Kategori } & \multicolumn{2}{c}{ Jumlah } \\
\cline { 2 - 7 } & \multicolumn{2}{c}{ Baik } & \multicolumn{2}{c}{ Cukup } & \multicolumn{2}{c}{ Kurang } & \multicolumn{2}{c}{} \\
\cline { 2 - 7 } & $\mathrm{f}$ & $\%$ & $\mathrm{f}$ & $\%$ & $\mathrm{f}$ & $\%$ & $\mathrm{~F}$ & $\%$ \\
\hline 20-30 tahun & 0 & 0 & 2 & 66,67 & 1 & 33,33 & 3 & 100 \\
31-40 Tahun & 0 & 0 & 6 & 50 & 6 & 50 & 12 & 100 \\
>40 Tahun & 0 & 0 & 6 & 54,55 & 5 & 45,45 & 11 & 100 \\
\hline Jumlah & 0 & 0 & 14 & 53,85 & 12 & 46,15 & 26 & 100 \\
\hline
\end{tabular}

Berdasarkan tabel diatas menunjukan bahwa dari 26 responden 14 responden yang berusia 20-30 tahun, 3140 tahun dan $>40$ tahun memiliki tingkat pengetahuan cukup $(53,85 \%)$, sedangkan 12 responden yang berusia 20-30 tahun, 31-40 tahun dan $>40$ tahun memiliki tingkat pengetahuan kurang $(46,15 \%)$.

Tabel 2. Tabulasi Silang Tingkat Pengetahuan Petugas Berdasarkan Lama Kerja

\begin{tabular}{ccccccccc}
\hline Lama Kerja & \multicolumn{9}{c}{ Kategori } & \multicolumn{2}{c}{ Jumlah } \\
\cline { 2 - 7 } & \multicolumn{2}{c}{ Baik } & \multicolumn{2}{c}{ Cukup } & \multicolumn{2}{c}{ Kurang } & & \\
\cline { 2 - 7 } & $\mathrm{f}$ & $\%$ & $\mathrm{f}$ & $\%$ & $\mathrm{f}$ & $\%$ & $\mathrm{~F}$ & $\%$ \\
\hline 1-5 Tahun & 0 & 0 & 4 & 66,67 & 2 & 33,33 & 6 & 100 \\
6-10 Tahun & 0 & 0 & 2 & 28,57 & 5 & 71,43 & 7 & 100 \\
$>$ 10 Tahun & 0 & 0 & 8 & 61,54 & 5 & 38,46 & 13 & 100 \\
\hline Jumlah & 0 & 0 & 14 & 53,85 & 12 & 46,15 & 26 & 100 \\
\hline
\end{tabular}

Berdasarkan tabel diatas menunjukan bahwa dari 26 responden 14 responden yang terdiri dari responden dengan lama kerja 1-5 tahun 4 orang, lama kerja 6-10 tahun 2 orang dan $>10$ tahun 8 orang memiliki tingkat pengetahuan cukup $(53,85 \%)$ sedangkan 12 responden yang terdiri dari responden dengan lama kerja 1-5 tahun 2 orang, 610 tahun 5 orang dan $>10$ tahun 5 orang memiliki tingkat pengetahuan kurang $(46,15 \%)$. 
4 | Indonesian Journal of Health Information Management (IJHIM), Vol. 2 No. 1 (2022),

Tabel 3. Tabulasi Silang Tingkat Pengetahuan Petugas Berdasarkan Jenis Kelamin

\begin{tabular}{ccccccccc}
\hline Jenis Kelamin & \multicolumn{9}{c}{ Kategori } & \multicolumn{2}{c}{ Jumlah } \\
\cline { 2 - 7 } & \multicolumn{2}{c}{ Baik } & \multicolumn{2}{c}{ Cukup } & \multicolumn{2}{c}{ Kurang } & & \\
\cline { 2 - 7 } & $\mathrm{f}$ & $\%$ & $\mathrm{f}$ & $\%$ & $\mathrm{~F}$ & $\%$ & $\mathrm{~F}$ & $\%$ \\
\hline Laki - Laki & 0 & 0 & 1 & 50,00 & 1 & 50,00 & 2 & 100 \\
Perempuan & 0 & 0 & 13 & 54,17 & 11 & 45,83 & 24 & 100 \\
\hline Jumlah & 0 & 0 & 14 & 53,85 & 12 & 46,15 & 26 & 100 \\
\hline
\end{tabular}

Berdasarkan tabel diatas

sedangkan 12 responden yang terdiri dari menunjukan bahwa dari 26 responden 14 responden yang terdiri dari laki-laki 1 orang dan perempuan 13 orang memiliki tingkat pengetahuan cukup $(53,85 \%)$ laki-laki 1 orang dan perempuan 11 orang memiliki tingkat pengetahuan kurang $(46,15 \%)$.

\section{Gambaran Tingkat Pengetahuan Petugas tentang Sistem Informasi Kesehatan Daerah (SIKDA) Generik}

Tabel 4. Distribusi Frekuensi Tingkat Pengetahuan Petugas tentang Sistem Informasi Kesehatan Daerah (SIKDA) Generik

\begin{tabular}{cccc}
\hline No & Tingkat Pengetahuan & Frekuensi & Persentase (\%) \\
\hline 1 & Baik & 0 & 0,00 \\
2 & Cukup & 11 & 42,31 \\
3 & Kurang & 15 & 57,69 \\
\hline \multicolumn{2}{c}{ Total } & 26 & 100,00 \\
\hline
\end{tabular}

Berdasarkan tabel diatas menunjukan bahwa dari 26 responden tingkat pengetahuan petugas tentang Sistem Informasi Kesehatan Daerah
(SIKDA) Generik nilai tertinggi pada kategori Kurang $(57,69 \%)$ dan nilai terendah pada kategori baik $(0 \%)$.

\section{Gambaran Tingkat Pengetahuan Petugas tentang Sistem Informasi Kesehatan Daerah (SIKDA) Generik di Pendaftaran}

Tabel 5. Distribusi Frekuensi Tingkat Pengetahuan Petugas Tentang Sistem Informasi Kesehatan Daerah (SIKDA) Generik di Bagian Pendaftaran

\begin{tabular}{|c|c|c|c|}
\hline No & Tingkat Pengetahuan & Frekuensi & Persentase $(\%)$ \\
\hline 1 & Baik & 8 & 30,77 \\
\hline 2 & Cukup & 16 & 61,54 \\
\hline 3 & Kurang & 2 & 7,69 \\
\hline \multicolumn{2}{|r|}{ Total } & 26 & 100 \\
\hline
\end{tabular}

Berdasarkan tabel diatas menunjukan bahwa dari 26 responden tingkat pengetahuan tertinggi petugas tentang Sistem Kesehatan Daerah
(SIKDA) Generik di bagian pendaftaran pada kategori cukup (61,54\%), sedangkan tingkat pengetahuan terendah pada kategori kurang $(7,69 \%)$. 
Gambaran Tingkat Pengetahuan Petugas tentang Sistem Informasi Kesehatan Daerah (SIKDA) Generik di Input Data Hasil Pemeriksaan

Tabel 6. Distribusi Frekuensi Tingkat Pengetahuan Petugas Tentang Sistem Informasi Kesehatan Daerah (SIKDA) Generik di Bagian Input Data Hasil Pemeriksaan

\begin{tabular}{cccc}
\hline No & Tingkat Pengetahuan & Frekuensi & Persentase (\%) \\
\hline 1 & Baik & 0 & 0,00 \\
2 & Cukup & 0 & 0,00 \\
3 & Kurang & 26 & 100,00 \\
\hline & Total & 26 & 100,00 \\
\hline
\end{tabular}

Berdasarkan tabel 6 menunjukan bahwa tingkat pengetahuan petugas tentang Sistem Kesehatan Daerah
(SIKDA) Generik di bagian Input Data Hasil Pemeriksaan dari 26 responden dengan kategori kurang (100\%)

\section{Gambaran Tingkat Pengetahuan Petugas tentang Sistem Informasi Kesehatan Daerah (SIKDA) Generik di Pelaporan}

Tabel 7. Distribusi Frekuensi Tingkat Pengetahuan Petugas Tentang Sistem Informasi Kesehatan Daerah (SIKDA) Generik di Bagian Pelaporan

\begin{tabular}{cccc}
\hline No & Tingkat Pengetahuan & Frekuensi & Persentase (\%) \\
\hline 1 & Baik & 1 & 3,85 \\
2 & Cukup & 20 & 76,92 \\
3 & Kurang & 5 & 19,23 \\
\hline & Total & 26 & 100,00 \\
\hline
\end{tabular}

Berdasarkan tabel 7 menunjukan bahwa dari 26 responden tingkat pengetahuan petugas tertinggi tentang Sistem Informasi Kesehatan Daerah (SIKDA) Generik di bagian pelaporan pada kategori cukup $(76,92 \%)$, sedangkan terendah pada kategori baik $(3,85 \%)$.

\section{PEMBAHASAN}

Pengetahuan merupakan hasil dari tahu yang terjadi melalui proses sensoris khususnya mata dan telingan terhadap suau objek tertentu. Tingkat pengetahuan yang di ukur dalam penelitian ini yaitu tentang Sistem Informasi Kesehatan Daerah (SIKDA) Generik. Intrumen yang digunakan untuk mengukur tingkat pengetahuan ini dalam bentuk kuesioner yang berisi tentang Sistem Kesehatan Daerah (SIKDA) Generik secara umum, menu yang terdapat pada Sistem Kesehatan Daerah (SIKDA) Generik di bagian penftaran, input data hasil pemeriksaan dan pelaporan. Berdasarkan hasil penelitian tingkat pengetahuan petugas tentang Sistem Informasi Kesehatan Daerah (SIKDA) Generik di
Puskesmas Ciwaru dengan nilai tertinggi pada kategori Kurang $(57,69 \%)$ dan nilai terendah pada kategori baik (0\%).

\section{Berdasarkan Karakteristik Responden}

Satuan waktu yang mengukur waktu keberadaan suatu benda atau makhluk, baik yang hidup maupun yang mati disebut usia. Berdasarkan hasil penelitian menunjukan bahwa tingkat pengetahuan petugas tentang Sistem Informasi Kesehatan Daerah (SIKDA) Generik di UPTD Puskesmas Ciwaru sebanyak 14 responden memiliki tingkat pengetahuan yang cukup $(53,85 \%)$ sedangkan 12 responden memiliki tingkat pengetahuan kurang $(46,15 \%)$.

Suatu kurun waktu atau lamanya tenaga kerja itu bekerja di suatu tempat dikenal dengan Lama Kerja. Berdasarkan hasil penelitian menunjukan bahwa tingkat pengetahuan petugas tentang Sistem Informasi Kesehatan Daerah (SIKDA) Generik di UPTD Puskesmas Ciwaru 14 responden memiliki tingkat pengetahuan cukup $(53,85 \%)$ sedangkan 12 responden memiliki tingkat pengetahuan kurang $(46,15 \%)$. 


\begin{abstract}
Beberapa orang menganggap bahwa jenis kelamin berpengaruh terhadap tingkat pengetahuan seseorang. Berdasarkan hasil penelitian menunjukan bahwa tingkat pengetahuan petugas tentang SIKDA Generik yang dilihat berdasarkan jenis kelamin dari 26 responden 2 responden dengan jenis kelamin laki-laki 1 responden memiliki tingkat pengetahuan cukup (50\%) dan 1 responden memiliki tingkat pengetahuan kurang (50\%), sedangkan 24 responden dengan jenis kelamin perempuan 13 responden memiliki tingkat pengetahuan cukup $(54,17 \%)$ dan 11 responden memiliki tingkat pengetahuan kurang $(45,83 \%)$.
\end{abstract}

\section{Gambaran Tingkat Pengetahuan Petugas Tentang Sistem Informasi Kesehatan Daerah (SIKDA) Generik di Pendaftaran}

Berdasarkan hasil penelitian menunjukan bahwa tingkat pengetahuan petugas di bagian pendaftaran dari 26 responden sebagian besar petugas memiliki tingkat pengetahuan yang cukup $(61,54 \%)$, sedangkan petugas yang memiliki tingkat pengetahuan baik $(30,77 \%)$ dan kategori kurang $(7,69 \%)$. Tingkat pengetahuan petugas di bagian pendaftaran di UPTD Puskesmas Ciwaru sudah cukup baik, tetapi masih terdapat beberapa responden yang memiliki tingkat pengetahuan kurang baik, hal ini juga berkaitan dengan sosialisasi yang diberikan oleh Dinas Kesehatan belum efektif. Hasil analisis pada butir pernyataan yang diberikan kepada responden menunjukan bahwa terdapat 1 item pernyataan dengan nilai terendah yaitu pada pernyataan nomor 3, sedangkan terdapat 2 item pernyataan dengan nilai tertinggi yaitu pernyataan nomor 2 dan 5 .

Pernyataan nomor 3 yaitu Langkah-langkah dalam melakukan pendaftaran pasien lama diawali dengan petugas melakukan pencarian data pasien hanya berdasarkan nama, dan rekam medis, pada pernyataan ini sebagian besar responden menjawab salah. Pendaftaran pasien lama dapat dilakukan dengan melakukan pencarian data pasien terlebih dahulu dengan menggunaan nama pasien,rekam medis, nomor kartu keluarga, NIK, Kepala keluarga, tempat lahir, dan alamat.

Pernyataan nomor 2 Langkahlangkah dalam melakukan pendaftaran pasien baru yaitu memilih sub menu pendaftaran-pilih pendaftaran baru-isi data pasien-proses data, dari hasil jawaban responden terkait dengan item ini menunjukan bahwa seluruh responden telah mengetahui alur dari pendaftaran pasien pada SIKDA Generik. Pernyataan nomor 5 Langkah-langkah dalam melakukan pendaftaran pasien lama yaitu petugas melakukan pencarian pasienklik kunjungan-isi bagian daftarkan ke kunjungan-proses data, dari hasil jawaban yang diberikan oleh responden menunjukan bahwa seluruh responden telah mengetahui dan memahami alur pendaftaran pasien baik itu pasien baru atau pasien lama.

Gambaran Tingkat Pengetahuan Petugas Tentang Sistem Informasi Kesehatan Daerah (SIKDA) Generik di Bagian Input Data Hasil Pemeriksaan

Berdasarkan hasil penelitian di UPTD Puskesmas Ciwaru menunjukan bahwa tingkat pengetahuan petugas di bagian input data kurang (100\%). Hasil analisis pada 4 item pernyataan menunjukan bahwa terdapat 2 item pernyataan dengan nilai terendah yaitu pada pernyataan nomor 2 dan 4 ,sedangkan pernyataan dengan nilai tertinggi pada item nomor 3 .

Pernyataan nomor 2 Data diagnosa yang dimasukkan pada pelayanan rawat jalan berisi diagnosa, kode ICD 10, dan jenis diagnosa. Proses input data hasil pemeriksaan salah satunya terdapat data diagnosa yang di dalamnya berisi diagnosa dan kode ICD 10, Jenis diagnosa, dan Jenis kasus, sebagian besar responden menjawab salah pada pernyataan ini.

Pernyataan nomor 4 Pada pilihan status terdapat pilihan dirujuk, sembuh, rawat inap.Tampilan awal di menu pelayanan berisi poliklinik, jenis pelayanan, status, dan tanggal. Pilihan 
status pada pernyataan ini berisi "sudah dilayani" dan "belum dilayani" untuk memberikan informasi pada pengguna pasien yang sudah atau belum mendapatkan pelayanan. Sebagian besar responden menjawab salah pada pernyataan ini.

Pernyataan nomor 3 Perbedaan pengisian data pelayanan pasien rawat inap dengan rawat jalan yaitu data laboratorium. Proses input data hasil pemeriksaan memiliki perbedaan pengisian data pada aplikasi, pada pasien rawat jalan data yang harus di isi berupa identitas pasien, data pelayanan, data diagnosa, tindakan, alergi obat, laboratorium, dan data obat yang diberikan kepada pasien. Proses input data hasil pemeriksaan pada pasien rawat inap petugas mengisi identitas pasien, data pelayanan, diagnosa, tindakan, alegi obat, dan data obat yang diberikan kepada pasien.

\section{Gambaran Tingkat Pengetahuan Petugas Tentang Sistem Informasi Kesehatan Daerah (SIKDA) Generik di Bagian Pelaporan}

Berdasarkan hasil penelitian di UPTD Puskesmas Ciwaru menunjukan bahwa dari 26 responden tingkat pengetahuan petugas tentang SIKDA Generik di bagian pelaporan nilai tertinggi pada kategori cukup (76,92\%) dan nilai terendah pada kategori baik $(3,85 \%)$. Kegiatan Pelaporan di UPTD Puskesmas Ciwaru dilakukan secara elektronik dan manual, pelaporan yang dilakukan secara elektronik akan dikirimkan ke dinas kesehatan melalui email.

Hasil analisis dari 4 item pernyataan menunjukan bahwa sebagian besar petugas telah mengetahui tentang penggunaan SIKDA Generik di bagian pelaporan, hal ini di tunjukan hanya terdapat 1 tem pernyataan dengan nilai terkecil yaitu pernyataan 3. Pernyataan nomor 3 "Data yang telah di input hanya dapat dicetak dalam bentuk excel", sebagian besar responden memilih jawaban "benar". Hal ini belum sesuai dengan teori,pada pelaporan data yang telah di input dapat di cetak dalam bentuk. excel dan pdf, pada menu pelaporan terdapat pilihan cetak excel atau cetak pdf.

\section{SIMPULAN DAN SARAN}

Berdasarkan hasil dan pembahasan, maka dapat di simpulkan sebagai berikut: Tingkat Pengetahuan Petugas tentang Sistem Informasi Kesehatan Daerah (SIKDA) Generik di UPTD Puskesmas Ciwaru hanya terdapat pada kategori cukup dan kurang, hal ini berkaitan dengan usia, lama kerja dan jenis kelamin.

Tingkat Pengetahuan Petugas tentang Sistem Informasi Kesehatan Daerah (SIKDA) Generik di bagian pendaftaran dari 26 responden menunjukan bahwa nilai tertinggi pada kategori cukup $(61,54 \%)$ dan nilai terendah pada kategori kurang $(7,69 \%)$. Hasil analisis pada butir pernyataan yang diberikan kepada responden menunjukan bahwa terdapat 1 item pernyataan dengan nilai terendah yaitu pada pernyataan nomor 3 yaitu Langkah - langkah dalam melakukan pendaftaran pasien lama diawali dengan petugas melakukan pencarian data pasien hanya berdasarkan nama, dan rekam medis, pada pernyataan ini sebagian besar responden menjawab salah.

Tingkat Pengetahuan Petugas tentang Sistem Informasi Kesehatan Daerah (SIKDA) Generik di bagian input data menunjukan bahwa tingkat pengetahuan petugas pada kategori kurang (100\%). Hal ini berkaitan dengan pelaksanaan pelatihan yang masih kurang, dikarenakan pada saat pelatihan dari Dinas Kesehatan hanya 2 petugas yang mengikuti pelatihan tersebut. Hasil analisis menunjukan bahwa terdapat 2 item pernyataan dengan nilai terendah yaitu pada pernyataan nomor 2 dan 4 . Pernyataan nomor 2 yaitu Data diagnosa yang dimasukkan pada pelayanan rawat jalan berisi diagnosa, kode ICD 10, dan Pernyataan nomor 4 yaitu Pada pilihan status terdapat pilihan dirujuk, sembuh, rawat inap.dan jenis diagnosa sebagian responden menjawab salah. Sebagian besar responden menjawab salah pada kedua item pernyataan ini. 
8 | Indonesian Journal of Health Information Management (IJHIM), Vol. 2 No. 1 (2022),

Tingkat Pengetahuan Petugas tentang Sistem Informasi Kesehatan Daerah (SIKDA) Generik di bagian pelaporan menunjukan bahwa nilai tertinggi pada kategori cukup (76,92\%) sedangkan nilai terendah pada kategori baik $(3,85 \%)$. Hasil analisis menunjukan terdapat 1 item pernyataan dengan nilai terkecil pernyataan 3 yaitu Data yang telah di input hanya dapat dicetak dalam bentuk excel sebagian besar jawaban responden salah.

Upaya yang dapat dilakukan untuk meningkatkan pengetahuan petugas sebaiknya jika dilakukan sosialisasi kembali kepada petugas terkait dengan penggunaan Sistem Informasi Manajemen Puskesmas di UPTD Puskesmas Ciwaru dan membuat Standar Operasional Prosedur (SOP) dalam penggunaan Sistem Informasi Kesehatan Daerah (SIKDA) Generik di UPTD Puskesmas Ciwaru.

\section{DAFTAR RUJUKAN}

Aulia, Nadia Rizqi. (2017). Faktor Human, Organization, Dan Technology Dalam Penggunaan Aplikasi SIMPUS Untuk Pendaftaran Pasien di Puskesmas Mulyorejo Surabaya.The Indonesian
Journal of Public Health, Vol.12 No.2,(237-248)

Ruslihardy. (2020). Implementasi Sistem Informasi Kesehatan Daerah (SIKDA) Generik Pada Bagian Rawat Jalan di BLUD Puskesmas Rawat Inap Langgam.Jurnal Administrasi Politik dan Sosial, Vol.1 No.2

Surita, dan Hendry Andry. (2021). Analisis Implementasi Layanan E-Puskesmas Pada Pusat Kesehatan Masyarakat Di Kecamatan Bungaraya Kabupaten SIAK.Jurnal Kemunting Program Studi Ilmu Administrasi Negara,Vol,2 No.1/2021

Wiguna, Ary Syahputra. (2016). Tingkat Pengetahuan Petugas Rekam Terhadap Pelaksanaan Sistem Informasi Di Puskesmas Payung Kecamat Payung Kabupaten Karo Tahun 2016.Jurnal Ilmiah Perekam dan Informasi Kesehatan Imelda, Vol.1,No.2

Wulandari, Febrianti. (2016). Efektivitas Penerapan Layanan EPuskesmas Di Kota Makassar.Skripsi 